\title{
Morphosyntactic and morphophonological variation in Breton: a cross-generational perspective*
}

\section{Introduction}

\subsection{Socio-historical context}

Among the regional languages spoken in present-day France, Breton has the distinction of being the only Celtic language. With Welsh as its closest living relative, it is most definitely 'non-Romance', and this 'otherness' has helped its speakers establish its identity as a language in its own right, separate from French. Like the other langues régionales, however, political and social pressures over the course of the $19^{\text {th }}$ and $20^{\text {th }}$ centuries led to a significant decline in the number of speakers and its current status as an endangered language. The majority of today's speakers are elderly, but there is a growing number of younger speakers thanks to the language revitalisation movement that began gathering speed in the 1960s and 70s.

Although the Breton-speaking area had been slowly shrinking with the advance of French, the decline of the language accelerated sharply from the late $18^{\text {th }}$ century, in a pattern of political and social pressure that is all too familiar: in 1831 the Minister for Public Education stated "il faut absolumment détruire la langue bretonne" (Gwegen, 1975: 34). Children were later forbidden from speaking Breton in schools, and the language became heavily stigmatised. The First World War was a turning point in the decline of Breton, since it was around this time that monolingual speakers became a minority. Not only were 250000 Breton men killed in the First World War, but those who returned brought back a greater proficiency in French (Broudic, 1995). In the interwar years French became the language of

\footnotetext{
${ }^{*}$ I am very grateful to the editors of this special issue, and to three anonymous reviewers for their helpful and insightful comments on earlier versions of this article. The fieldwork for this study was supported by a travel grant from Jesus College, Oxford, and a British Academy Postdoctoral Fellowship.
} 
modernity and prosperity, spoken by an increasingly urban population, and by the early 1950s, intergenerational transmission of Breton had effectively ceased (Broudic, 2009).

Efforts by language activists to revitalise Breton led to the establishment of Bretonmedium schooling in the form of Diwan, which began in 1977 as a single école maternelle, separate from the state, and with the goal of enabling children to become bilingual in French and Breton (Bocquenet, 1985). The 1951 Loi Déixonne had permitted the teaching of regional languages in French schools, and while this was an important moment of recognition, the amount of Breton offered was small, and Diwan was set up in response to the perceived lack of opportunity for children to learn Breton (Kuter, 1999). It now covers the whole span of education (from age 2 to age 18) with schools across Brittany. Thus, a new group of younger speakers has emerged, separate from older traditional speakers who grew up speaking the language at home, and there is a gap in language transmission.

This sociohistorical context has led to new patterns of variation emerging in Breton, which this paper seeks to investigate, alongside reaching a better understanding of the following key issues:

- What characterises the Breton of younger speakers? How is it different from that of older speakers?

- What impact is contact with French (particularly among a bilingual population) having on Breton?

The paper also highlights the challenges faced in conducting research into variation in a minority language such as Breton. 


\subsection{New Speakers of Breton}

Le Nevez (2006: 165) writes that today there are three 'relatively distinct generations' of Breton speakers. The first comprises older traditional speakers, born before 1950, who grew up speaking the language with their parents. Their children form the second generation, who grew up speaking French, but may have a passive knowledge of Breton. Finally, the third generation comprises the 'new speakers', many of whom have learnt Breton almost entirely through immersion schooling, having grown up in French-speaking homes. This paper is concerned with Le Nevez's first and third generations of speakers, since these groups have an active command of the language.

The two groups differ quite substantially in a number of key characteristics. Older traditional speakers tend to use Breton with close family and neighbours of the same generation, and live in rural locations. They are generally not literate in Breton, having been schooled in French, and their language is sometimes termed breton populaire (Le Pipec, 2013). Some speakers have few opportunities to use the language, and may suffer from firstlanguage attrition effects. At the time of Broudic's (2009) large-scale survey 47 per cent of Breton speakers were aged over 75.

In contrast, younger speakers live in urban areas, and larger towns are more likely to have schools providing Breton-medium education. They are generally better educated and have better-paying employment opportunities than older speakers. Most come from Frenchspeaking backgrounds and having learnt the language at school, they are literate in Breton, though their speech may be influenced by the written form of their language (Le Ruyet, 2011). There are far fewer younger than older speakers: in 2007, only six per cent of speakers were aged under 40 (Broudic, 2009). 
Le Nevez (2006) refers to these groups as different 'generations' of speakers, and this is broadly true. However, the difference between these two groups is far from being simply a generational one, and the age range of each group is much wider than a single generation: given that the first Diwan school was founded in 1977, its first pupils are now likely to have children of their own. It therefore seems more appropriate to discuss these groups in terms of their linguistic background; that is, whether they should be considered 'traditional' or 'new' speakers. This in turn permits the Breton situation to be placed within the broader minority language context and the emerging concept of the 'new speaker'.

Recent research has begun to investigate the phenomenon of the 'new speaker' in a minority language context (Jaffe, 2015; McLeod and O'Rourke, 2015; Nance, 2015; Nance et al., 2016; NeSmith, 2003; O'Rourke, 2018; O'Rourke et al., 2015; Smith-Christmas et al., 2018). When dealing with widely spoken languages with large, diverse speaker communities, and an accepted standard variety, the question of what constitutes a first-language speaker is fairly easy to address. However, this is more difficult for endangered minority languages, where most speakers are elderly, and revitalisation efforts are attempting to increase the number of younger speakers. Hornsby (2015) defines new speakers as those who acquire the language by means other than intergenerational transmission, and there may be several different paths to 'speakerhood'. These new speakers may identify as first-language or second-language speakers, or neither, and the question of what exactly their language is like is currently the subject of research.

The language of younger Breton speakers is sometimes termed 'Neo-Breton' (Jones, 1995). It is a standardised variety (Jones, 1998a), and has been stigmatised as 'artificial' (Walter, 1999: 19) or a 'learner's variety' (Hornsby, 2005). This is not unique to Breton: Bentahila and Davies (1993) write that new standardised forms may alienate traditional 
speakers who might otherwise feel supported by increased interest in their language because the variety being promoted is unfamiliar. Equally, however, traditional native speakers may lack confidence in their own Breton (Adkins, 2013), and may regard standardised Breton as more “correct” (McDonald, 1989).

Even within the linguistic literature, there are claims that Neo-Breton is a restructured language. Jones (1998b) uses the term xenolect for Neo-Breton, writing that 'standardized Breton and the local dialects belong to totally different worlds' (Jones, 1998b: 326). Madeg (2010) goes further, likening Neo-Breton to a creole.

This prompts questions about what characterises new speakers' Breton, and how it might differ from that of traditional speakers. Hornsby (2005) collates a number of claims that have been made regarding Neo-Breton, summarised as follows:

- Lexis: Neo-Breton avoids French loanwords in favour of more 'Celtic' equivalents (Jones, 1995).

- Syntax: French influence has led to speakers generalising subject-initial word order, one of several options available in Breton (McDonald, 1989).

- Morphology: Some or all of the mutation is lost (Dressler, 1972) or confused (McDonald, 1989). The distinction between different forms of bezañ 'to be' is not always maintained (Hewitt, 1977).

Le Pipec (2013) writes that the term néo-bretonnants is itself ambiguous and can refer to two slightly different groups of speakers, namely, those who speak a Breton that is heavily influenced by French (regardless of age of acquisition), and those who acquire Breton through formal education. It can also refer to the children of new speakers, whose native language is Neo-Breton. This contrasts with the purely generational view of Breton speakers set out by Le Nevez (2006). 
New speakers are sometimes seen as arrogant - they do not want to learn 'authentic' Breton, and prefer the 'purist' Neo-Breton (McDonald, 1989), or lazy - they have not made the effort to learn 'authentic' Breton properly (Hewitt, 2017). Both of these viewpoints devalue Neo-Breton and delegitimise new speakers.

Recent research (e.g. Davies-Deacon, 2017; Kennard, 2018b; Kennard and Lahiri, 2017; Le Ruyet, 2011) investigates these views by examining the language used by new speakers, and comparing it to 'traditional' Breton. Two opposing forces can be identified in Neo-Breton: the influence of French, and the avoidance of French influence. For example, Kennard (2014) finds some younger speakers of Breton overuse subject-initial word order, under influence from French. Other younger speakers avoid subject-initial word order precisely because it is associated with French-influenced Breton and an imperfect command of the language, and will use non-subject-initial alternatives even where older traditional speakers would use subject-initial word order.

Hornsby (2017: 98) writes: 'there are probably as many ways of speaking Breton as there are speakers', and it would be a mistake to think that Neo-Breton is a single, homogeneous variety. Interspeaker variation may be conditioned by a speaker's language background - the language of their parents, grandparents, or other family members (Jouitteau, 2018; Kennard, 2014), the age of acquisition (Goalabré, 2011), and, if they attended Breton-medium education, the type of education that was (Kennard, 2014). Also relevant may be the speaker's attitude to Breton (Baudu, 2015; Hoare, 2000; Le Coadic, 2013), whether they consider themselves to be a native speaker (Dołowy-Rybińska, 2016; Le Coadic, 2013), and their current linguistic practices - whether they speak it at home, at work, and how often (Dołowy-Rybińska, 2016). As Le Pipec (2013) notes, speakers may change the way in which they speak Breton as they become more aware of French influence and wish to 
sound more 'authentically' Breton. The question of what Neo-Breton is like is therefore far from straightforward.

To investigate further how younger speakers of Breton use the language, to what extent they are influenced by French, and what variation there is in modern Breton, this paper examines two linguistic phenomena. The first is morphosyntactic: a type of impersonal verb construction; the second is morphophonological, and concerns nominal mutation. These have been chosen for two main reasons: first, Neo-Breton is said to differ from traditional Breton in terms of its morphology, with speakers omitting or becoming confused about mutation. This is an ideal opportunity to investigate to what extent these claims are true, and whether they are representative of Neo-Breton speakers as a whole. Secondly, other studies of language obsolescence and revitalisation have found interesting patterns in morphological data. Dorian, for example, examines both mutation and complex morphology in less fluent speakers of East Sutherland Gaelic, and finds loss within the mutation system and levelling of complex morphological structures (Dorian, 1973; 1978). The next sections present the background and data for impersonals and mutation, and these are followed by a general discussion.

\section{Impersonals}

\subsection{Background: Breton impersonal constructions}

The impersonal constructions which form the subject of discussion here, indirect impersonal verbs, form one of several types of impersonal construction in Breton (Hemon, 1975: 270-271; Hewitt, 2002: 24-26; Ternes, 1992: 394). These utterances are characterised by the fact that what might be understood semantically as the subject does not appear in the usual, nominative position, but rather in a prepositional phrase with $d a$ 'to'. 
(1) Indirect impersonal constructions ${ }^{1}$
a. soñjal a ra din
think.VN PRT do.3sG to.1SG
'I think.'
b. plijout a ra d' ar plac'h please.VN PRT do.3SG to DET girl 'The girl likes it.'

(2) Non-impersonal constructions
a. kanañ a ran sing.VN PRT do.1SG 'I sing.'
b. debriñ a ra ar plac'h avaloù eat.VN PRT do.3SG DET girl apples 'The girl eats apples.'

The examples in (1) are thus analogous to various 'dative constructions' found crosslinguistically (Moore and Perlmutter, 2000). They contrast with the non-impersonal Breton patterns given in (2).

These constructions are not without variation; Press (1986) notes that some of the verbs can be used in normal, personal constructions, usually with a slightly different meaning (e.g. 'to like' vs. 'to please'). Textbooks and grammars (e.g. Hemon, 1941; Ternes, 1992) also give examples of these verbs in both personal and impersonal constructions.

There are several different word order options available in Breton, and constructions with impersonal verbs are no exception. Breton has a verb-second constraint in matrix clauses, and the choice of the initial constituent is largely pragmatically determined (Press,

\footnotetext{
${ }^{1}$ Glosses follow the Leipzig Glossing Rules, and the following abbreviations are used: $1=1^{\text {st }}$ person, $2=2^{\text {nd }}$ person, 3 = $3^{\text {rd }}$ person, DET = determiner, DIM = diminutive, NEG = negative marker, $\mathrm{PL}=$ plural, $\mathrm{PROG}=$ progressive, $\mathrm{PRT}=$ preverbal particle, $\mathrm{SG}=$ singular, $\mathrm{UNIN}=$ uninflected form, $\mathrm{VN}=$ verbal noun.
} 
2009). In a pragmatically neutral context speakers are likely to place either the subject or a non-finite verb in initial position, and examples are given in (3). In non-negative utterances, there is no verbal agreement with an overt subject.

(3) a. S-initial

$$
\begin{aligned}
& \text { avaloù a blij } \quad \mathrm{d}^{\prime} \text { ar plac'h } \\
& \text { apples PRT please.3SG to DET girl } \\
& \text { 'The girl likes apples.' }
\end{aligned}
$$

b. VN-initial

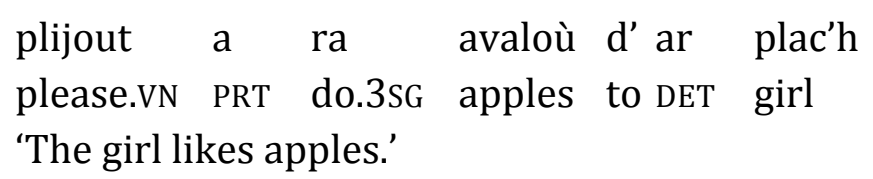

Utterances with a pronominal subject are more complex, as shown in (4) and (5). When the verbal noun is initial, there is no overt subject, and the auxiliary agrees with the subject. In (4a) non-impersonal kanañ 'to sing' is combined with an auxiliary inflected for the first person singular, while in (4b) the auxiliary has third person singular agreement and a first person inflected preposition, reflecting its impersonal nature.

In contrast the examples in (5) have a pronoun in initial position. In (5a) this is the subject, and so the verb is not inflected. Although it may look as though (5b) has both a personal and impersonal subject, Press (1986) and Hewitt (2002) argue that in this sentence the pronoun me is a fronted topic.

(4) VN-initial - pronominal

a. Non-impersonal

kanañ a ran

sing.VN PRT do.1SG

'I sing.'

b. Impersonal

$\begin{array}{llll}\text { soñjal } & \text { a } & \text { ra } & \text { din } \\ \text { think.VN } & \text { PRT } & \text { do.3SG } & \text { to.1SG } \\ \text { 'I think.' } & & & \end{array}$


(5) S-initial - pronominal

a. Non-impersonal

$$
\begin{array}{lll}
\text { me a } & \text { gan } \\
\text { I } \quad \text { PRT } & \text { sing.3SG } \\
\text { 'I sing.' } &
\end{array}
$$

b. Impersonal

$$
\begin{array}{lll}
\text { me a } & \text { soñj } & \text { din } \\
\text { I PRT } & \text { think.3SG } & \text { to.1sG } \\
\text { 'I think.' } & &
\end{array}
$$

Hewitt (2002) uses evidence from agreement patterns to show this. Negative utterances have verbal agreement with an initial subject, in contrast with non-negative utterances such as (3). There is a contrast between impersonal and non-impersonal negative utterances in terms of agreement patterns, indicating that the initial pronoun in impersonal constructions is a topic, not a subject.

(6) Negative utterances

a. Non-impersonal

$$
\begin{array}{lll}
\text { me ne gan-an ket } \\
\text { I NEG sing-1SG NEG } \\
\text { 'I do not sing.' }
\end{array}
$$

b. Impersonal

$$
\begin{array}{llll}
\text { me ne soñj } & \text { ket } & \text { din } \\
\text { I } & \text { NEG think.3SG } & \text { NEG } & \text { to.1SG } \\
\text { 'I do not think.' } & &
\end{array}
$$

c. *me ne soñj-an ket din

I NEG think-1SG NEG to.1SG

Example (6c), with agreement on the verb, is ungrammatical. 


\subsection{Impersonals: methodology}

The impersonal data were collected during two fieldwork visits, eighteen months apart, to south-west Brittany, as part of a larger study on Breton morphosyntax. This area is within the kerneveg dialect region, and varieties spoken in this region may differ from the standard, which is based largely on northern varieties (German, 2007).

Three groups of speakers were interviewed as part of the study: first, five traditional speakers (senior adults) who had grown up speaking Breton, and spoke little French before attending school. They live in small rural villages and were aged between 70 and 85 at the time of the study (mean age $=74.4$ ). All had a close family member with whom they spoke Breton regularly. The two other groups can be considered 'new speakers' of Breton; first, nine young adults aged between 20 and 35 (mean age = 31.2), who had acquired Breton outside the home, usually through education. They were employed in areas where they used Breton daily, such as Breton-language media or teaching. The second group comprised 13 children aged between 8 and 15 (mean age $=11.25$ ), who came from French-speaking homes, but were attending Breton-medium schooling, either Diwan or the state Div Yezh stream.

The data were elicited using photographs which portrayed people and animals carrying out actions (e.g. dancing, eating, playing). Participants were asked to say what was happening, or what they thought about the prompt, depending on the task. The tasks were explained in French, to ensure that all speakers understood what was required, and to avoid the use of Breton by a second-language learner, which speakers might have found strange. Speakers then viewed the series of prompts without interruption.

The goal was to elicit a range of different syntactic structures, including those with impersonal verbs, in as neutral a context as possible. Given that Breton word order is flexible, the use of the single prompt "what's happening?" aimed to avoid topicalisation, and it was 
expected that speakers would use either subject-initial or verbal noun initial word order (as described in Section 2.1). ${ }^{2}$

This method was chosen over translation due to concerns that this would lead to French-influenced syntax. This was borne out by a pilot study: speakers were more likely to use subject-initial word order when translating a French sentence into Breton than when producing a Breton sentence spontaneously (Kennard, 2013). It also avoided any reading, since the senior adults are not literate in Breton.

Given the minority language context, some degree of variability is expected. Older speakers may show regional variation, while among the younger speakers, the different degrees of exposure to Breton and the mode of acquisition may play a role. Chauffin (2015) writes that only rarely are teachers in Diwan schools native Breton speakers themselves: most have acquired the language either through schooling, or as a second language. She also points out that the educational context may lead to children missing out on familiar registers of the language: 'Comment dire les mots d'amour à un bébé, ou à un petit garçon, en breton?' (Chauffin, 2015: 146).

With this context in mind, what patterns of variation do we expect to find for impersonal constructions? The senior adults may closely resemble the descriptive accounts given in section 2.1; alternatively, regional variation may mean that they differ, perhaps not using one or more of these constructions impersonally. Although they are fluent speakers of French, we do not expect to see extensive French influence in their data, because they all have Breton as a first language and use it regularly.

For the young adults and children, we can imagine two extremes. They might be heavily influenced by French, and completely drop the impersonal from these constructions:

\footnotetext{
${ }^{2}$ For further discussion, see Jouitteau $(2005 ; 2010 ; 2011)$ and Kennard $(2014 ; 2018 a)$.
} 
Campbell and Muntzel (1989) find that it is usual in language obsolescence and consequent restructuring to see syntactic reduction, and the use of more transparent constructions. Alternatively, they might maintain the impersonal nature of these verbs, potentially to a greater extent than the senior adults if the latter show variability of the type discussed above. With regard to the children specifically, they may be different again if they have not yet fully acquired the system of impersonal verbs.

\subsection{Impersonals: findings}

Looking at the data overall, we find intergroup differences regarding the use of impersonals. The data in Table 1 show the number of potential impersonal constructions, and whether these take an impersonal or a non-impersonal form. They consist of the verbs soñjal 'to think', krediñ 'to believe, think', kavout 'to find', fellout 'to want, need' and plijout 'to please', as well as constructions such as gwelloc' $h$ eo 'it is better'.

Table 1. Impersonal constructions: overall

\begin{tabular}{llllc}
\hline Group & \multicolumn{2}{l}{ Impersonal } & \multicolumn{2}{l}{ Non-impersonal } \\
\hline Senior adults & 31 & $56.3 \%$ & 24 & $43.6 \%$ \\
Young adults & 92 & $71.3 \%$ & 37 & $28.7 \%$ \\
Children & 12 & $10.8 \%$ & 99 & $89.2 \%$ \\
\hline
\end{tabular}

The young adults use more impersonal constructions than the other groups, and the children use many more non-impersonal constructions. A chi-squared test shows that the difference between the groups is significant $\left(\mathrm{X}^{2}=91.0651, p<0.001\right)$, but since there are three groups involved, it is difficult to see what is driving this significant result. The chisquared residuals are reported in Table 2, and indicate that this significant result is driven by the children's data. 
Table 2. Impersonal constructions: overall - chi-squared residuals in italics

\begin{tabular}{lllll}
\hline Group & \multicolumn{2}{l}{ Impersonal } & \multicolumn{2}{l}{ Non-impersonal } \\
\hline Senior adults & 31 & $56.3 \%$ & 24 & $43.6 \%$ \\
Young adults & $X^{2} R=1.35$ & & $X^{2} R=1.14$ & \\
& 92 & $71.3 \%$ & 37 & $28.7 \%$ \\
Children & $X^{2} R=18.41$ & & $X^{2} R=15.53$ & \\
& 12 & $10.8 \%$ & 99 & $89.2 \%$ \\
& $X^{2} R=29.63$ & & $X^{2} R=25.00$ & \\
\hline
\end{tabular}

Further post-hoc tests give additional insight. Running chi-squared tests on individual pairs of comparisons naturally entails running multiple tests on the same data, and so the Bonferroni correction must be applied, ${ }^{3}$ giving a significance level of $p<0.016$; the comparison between the Senior Adults and Young Adults is therefore not significant.

Table 3. Impersonal data overall - 2x2 comparisons

\begin{tabular}{ll}
\hline Comparison & Result \\
\hline SA x YA & $X^{2}=3.891, p=0.049$. \\
SA x Children & $X^{2}=39.760, \boldsymbol{p}<\mathbf{0 . 0 0 1}$. \\
YA x Children & $X^{2}=88.954, \boldsymbol{p}<\mathbf{0 . 0 0 1 .}$ \\
\hline
\end{tabular}

Both adult groups differ from the children, who use far more non-impersonal constructions. This might suggest change in progress, but given the age of the children, it could equally be an effect of continued acquisition of Breton, and it is difficult to be certain. As Palosaari and Campbell (2011) note, changes in endangered language situations may be the result of imperfect learning, language obsolescence, or simply 'normal' change, and these may be difficult to disentangle.

Looking at the data overall gives an idea of general tendencies, but may obscure other factors. Examining the data more closely, it is immediately clear that there is variation between the groups in terms of which verbs or constructions they use (Table 4).

Table 4. Verbs and constructions by group

3 This method is suggested by McDonald (2014). 


\begin{tabular}{lllll}
\hline Verb/Construction & $\begin{array}{l}\text { Senior } \\
\text { Adults }\end{array}$ & Young Adults & Children & Total \\
\hline fellout 'to want, need' & 0 & 3 & 0 & 3 \\
kavout 'to find' & 11 & 12 & 0 & 23 \\
krediñ 'to believe, think' & 27 & 12 & 13 & 52 \\
plijout 'to please' & 1 & 36 & 8 & 45 \\
soñjal 'to think' & 16 & 65 & 90 & 171 \\
gwelloc'h eo 'it is better' & 0 & 1 & 0 & 1 \\
\hline
\end{tabular}

Fellout and gwelloc'h eo are marginal in the data, and therefore cannot shed light on the use of impersonals across the speaker groups. Equally, not all verbs are used by all groups of speakers: kavout is used only by the senior and young adults, while plijout is used predominantly by the young adults and children. It is therefore not possible to undertake statistical analysis of the data that combines verb type and speaker group (such as a generalised linear model), and the different verbs will be examined separately.

Looking first at kavout (Table 5), there is a clear difference between speaker groups, which a Fisher's exact test shows to be statistically significant ( $p=0.0137)$.

Table 5. Use of kavout 'to find'

\begin{tabular}{lll}
\hline kavout 'to find' & Impersonal & Non-impersonal \\
\hline Senior adults & 0 & 11 \\
Young adults & 6 & 6 \\
\hline
\end{tabular}

The senior adults never use kavout in an impersonal construction, while the young adults do in half of all utterances. However, the two groups seem to be using kavout in different ways, as example (7) shows.

(7) a. Speaker J (SA)

Pêr gav mat gwastell

Pêr find.3sG good cake

'Pêr finds cake good.' 
b. Speaker L (YA)

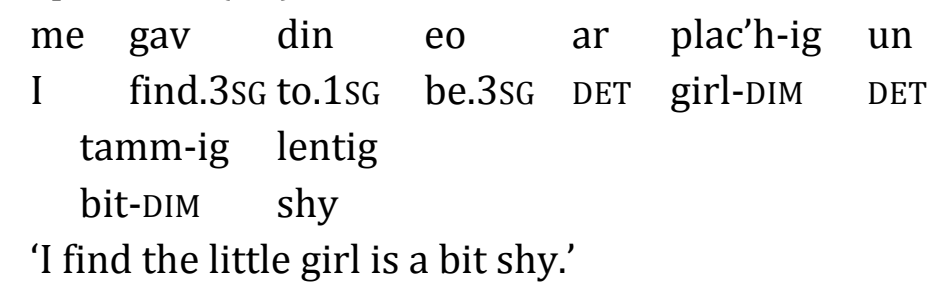

The senior adults tend to use kavout with a noun phrase and an adjective, such as 'find X good'; (7a) could equally well be translated as 'Pêr likes cake'. The young adults tend to use kavout with a clause as the complement $(7 \mathrm{~b})$, with the result that the meaning is closer to 'think' than 'find'. This subtle difference in usage might explain why the proportion of impersonal utterances differs. Additionally, of the six instances in the Young Adults' data where kavout is not used impersonally, one is the same as (7a), and three are tag-like questions, as in (8).

(8) Speaker L (YA)

n' eo ket e vamm-gozh; e

NEG be.3SG NEG his grandmother; his

vamm-guñv, gav te?

great-grandmother, find.3sG you?

'That's not his grandmother; [it's] his great-grandmother, don't you think?'

Kavout is also used impersonally in a tag question, but there is only one example in the data (see (9)).

(9) Speaker L (YA)

muiañ zo da zebriñ se, gav dit?

best be.UNIN to eat.vN that, find.3SG to.2SG?

'It's great to eat that, don't you think?'

Of course, tag-questions syntactically different from matrix clauses, and are potentially clouding the results; they are excluded in Table 6. 
Table 6. Use of kavout 'to find'

\begin{tabular}{lll}
\hline kavout 'to find' & Impersonal & Non-impersonal \\
\hline Senior adults & 0 & 11 \\
Young adults & 5 & 3 \\
\hline
\end{tabular}

A Fisher's exact test indicates that there is still a significant difference between the two groups of speakers $(p=0.0043)$. It seems then that there may be a number of factors affecting the use of impersonals with kavout, and that the difference between the two speaker groups is partly driven by the type of utterance they produce. It is also interesting that only the younger adults use tag-questions of the types in (8) and (9), and these are not found in the responses from the senior adults. Further investigation, perhaps involving a larger corpus, would be needed to find out whether this is a generational difference.

In contrast, the verb plijout 'to please' is used almost exclusively by the children and young adults; the single usage by a senior adult will not be considered here. As Table 7 shows, plijout is strongly impersonal across all speakers, and a Fisher's exact test shows that there are no significant differences.

Table 7. Use of plijout 'to please'

\begin{tabular}{lll}
\hline plijout $^{\text {'to please' }}$ & Impersonal & Non-impersonal \\
\hline Young adults & 35 & 1 \\
Children & 7 & 1 \\
\hline
\end{tabular}

The number of instances of plijout among the children is quite small; however, the data do seem to indicate that, contrary to the findings for impersonal verbs as a whole, the children use plijout predominantly impersonally. This might be because French has an equivalent impersonal verb with the same meaning, and the construction is therefore very similar in the two languages, as shown in example (10). 
(10) a. plijout 'to please'

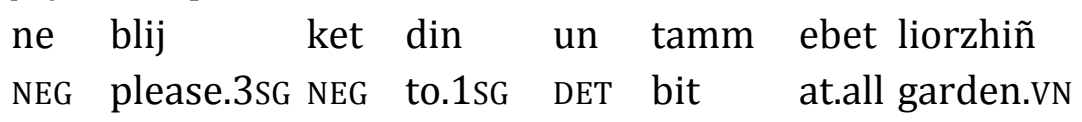

'I don't like gardening at all.'

Speaker C (YA)

b. plaire 'to please'

le jardinage ne me plaît pas du tout

DET gardening NEG me please.3SG NEG of all

'I don't like gardening at all.'

The similarity of the French structure may be reinforcing the impersonal nature of this verb in Breton among younger speakers. It might seem odd that this is only a factor for the younger speakers, and not the older speakers, who are also fluent in French. However, as discussed above, younger speakers of Breton tend to come from French-speaking homes, and may therefore be French-dominant, or more susceptible to influence from French. Although Neo-Breton is inclined to avoid French loanwords, French influence is often observable in the syntax (German, 2007; McDonald, 1989).

In addition, barring a single exception, the senior adults do not use plijout, instead using a different construction with the noun plijadur 'pleasure, enjoyment' (11).

(11) plijadur

a. Speaker K

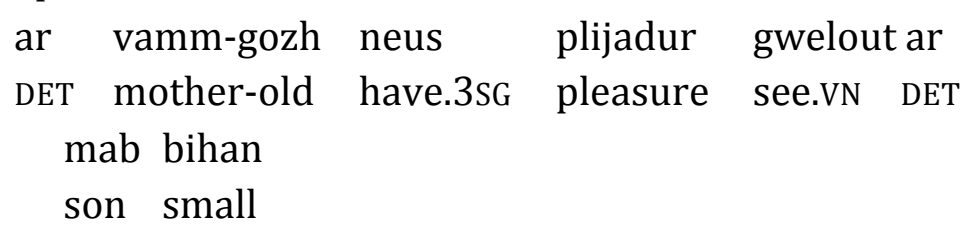

'The grandmother likes to see her grandson.' 
b. Speaker J

kalz plijadur zo peogwir emañ an
lots.of pleasure be.UNIN because be.SIT.3SG DET
tud $\quad[\mathrm{o}]$ tañsal
people PRT dance.PROG
'There's lots of enjoyment because the people are dancing.'

c. Speaker QN

plijadur dezho klask o boued pleasure to.3PL seek.VN their food

'They like to look for their food.'

Plijadur is most commonly used with kaout 'to have', as in example (11a), but it is also found in an existential construction as in (11b), with the meaning 'there is enjoyment', or 'everyone is enjoying themselves'. Occasionally it is found with the preposition $d a$ 'to' (11c), a construction similar to the impersonal verbs under discussion here. ${ }^{4}$ Fundamentally though, these constructions are quite different: plijout and plijadur are different parts of speech, and the constructions use a different tensed verb. This is interesting because it implies that although the younger speakers are using plijout more often in an impersonal construction, the senior adults generally use several different constructions to express liking or pleasure.

Turning now to krediñ 'to think, believe', for the first time it is possible to make a threeway comparison across the speaker groups. The data for kredin are given in Table 8 , and it is immediately apparent the children differ from the adults, never using this verb impersonally.

\footnotetext{
4 Of 46 instances of plijadur in the Senior Adults' data, 38 used kaout, six used bezañ in an existential construction, and two used $d a$.
} 
Table 8. Use of krediñ 'to think, believe'

\begin{tabular}{lllll}
\hline krediñ & Impersonal & \multicolumn{2}{c}{ Non-impersonal } \\
\hline Senior adults & 18 & $66.7 \%$ & 9 & $33.3 \%$ \\
& $X^{2} R=1.39$ & & $X^{2} R=-1.34$ & \\
Young adults & 7 & $58.3 \%$ & 5 & $41.7 \%$ \\
& $X^{2} R=0.51$ & & $X^{2} R=-0.49$ & \\
Children & 0 & $0 \%$ & 13 & $100 \%$ \\
& $X^{2} R=-2.5$ & & $X^{2} R=-2.41$ & \\
\hline
\end{tabular}

A chi-squared test shows that there are significant differences $\left(\mathrm{X}^{2}=16.28, p<0.001\right)$, and the standardised residuals indicate that the children's data are driving this finding. This is confirmed by further post-hoc tests (Table 9).

Table 9. Use of krediñ - 2x2 comparisons using Fisher's exact test

\begin{tabular}{ll}
\hline Comparison & Result \\
\hline SA x YA & $p=0.723$ \\
SA x Children & $\boldsymbol{p}<\mathbf{0 . 0 0 1}$ \\
YA x Children & $\boldsymbol{p}=\mathbf{0 . 0 0 2}$ \\
\hline
\end{tabular}

Exactly the same pattern can be observed for soñjal 'to think'. Table 10 shows that the children are strikingly different from the adults, and a chi-squared test shows significant differences $\left(\mathrm{X}^{2}=70.417, p<0.001\right)$; the standardised residuals indicate that this result is driven by the children's data.

Table 10. Use of soñjal 'to think'

\begin{tabular}{lllll}
\hline soñal & Impersonal & \multicolumn{2}{c}{ Non-impersonal } \\
\hline Senior adults & 13 & $81.2 \%$ & 3 & $18.8 \%$ \\
& $X^{2} R=3.25$ & & $X^{2} R=-2.32$ & \\
Young adults & 40 & $61.5 \%$ & 25 & $38.5 \%$ \\
& $X^{2} R=3.79$ & & $X^{2} R=-2.74$ & \\
Children & 5 & $5.6 \%$ & 85 & $94.4 \%$ \\
& $X^{2} R=-4.62$ & & $X^{2} R=3.31$ & \\
\hline
\end{tabular}

Post-hoc tests show that the two groups of adults are not significantly different from one another. 
Table 11. Use of soñjal - 2x2 comparisons using Fisher's exact test

\begin{tabular}{ll}
\hline Comparison & Result \\
\hline SA x YA & $p=0.240$ \\
SA x Children & $\boldsymbol{p}<\mathbf{0 . 0 0 1}$ \\
YA x Children & $\boldsymbol{p}<\mathbf{0 . 0 0 1}$ \\
\hline
\end{tabular}

It is interesting to note that while soñjal is the most commonly used verb for 'to think' among the younger adults and children, the senior adults prefer kredin. ${ }^{5}$ This points to another lexical difference (in addition to plijout/plijadur) between the two speaker groups.

Up to this point, the discussion has focused on interspeaker and intergroup variation, but not intraspeaker variation. Due to the relatively small size of the data set, exploring intraspeaker variation is not entirely straightforward: counts of each verb for individual speakers can be quite low, making it difficult to spot patterns in usage. However, the data from soñjal are more promising: four speakers use soñjal on at least nine occasions, both impersonally and non-impersonally. They are: J (senior adult), D and H (young adults) and CG (child), and their data are presented in Table 12.

Table 12. Intraspeaker variation

\begin{tabular}{lll}
\hline soñjal 'to think' & Impersonal & Non-impersonal \\
\hline J (senior adult) & 6 & 3 \\
D (young adult) & 15 & 3 \\
H (young adult) & 7 & 12 \\
CG (child) & 4 & 7 \\
\hline
\end{tabular}

The data from these four speakers suggest a range of factors may be at work in determining their choice of impersonal construction, even in this very restricted pragmatic context. Speaker J's data are the least clear: he uses soñjal in the same sort of construction both impersonally and non-impersonally, as in (12).

5 Younger speakers (adults and children): 13.9\% krediñ; $86.1 \%$ soñjal. Older speakers: $62.8 \%$ krediñ; 37.2\% soñjal. 
(12) Speaker J (SA)

a. Impersonal

me [a] soñj din la ar vaouez neus

I [PRT] think.3SG to.1SG that DET woman have.3SG

aon lakaat nadoz barzh he bezh

fear put.vN needle in her finger

'I think the woman is afraid of sticking the needle in her

finger.'

b. Non-impersonal

me [a] soñj din la ar vaouez a

I [PRT] think.3SG to.1SG that DET woman PRT

zo [o] c'houl un dra bennak

be.UNIN [PRT] ask.PROG DET thing some

'I think the woman is asking something.'

The only additional thing to note is that when he uses soñjal in the present perfect, he does so non-impersonally.

The data from Speaker D may be more illuminating. Most of his responses are impersonal, and all have the form in (13a), with an initial pronoun and a single clause. However, when he uses soñjal in a clause preceded by another statement, he does not use the impersonal (13b). This second clause is missing any person/number agreement with the subject, so it could be an ellipsis, added as an afterthought. Additional data would be needed to be more certain.

(13) Speaker D (YA)

a. Impersonal

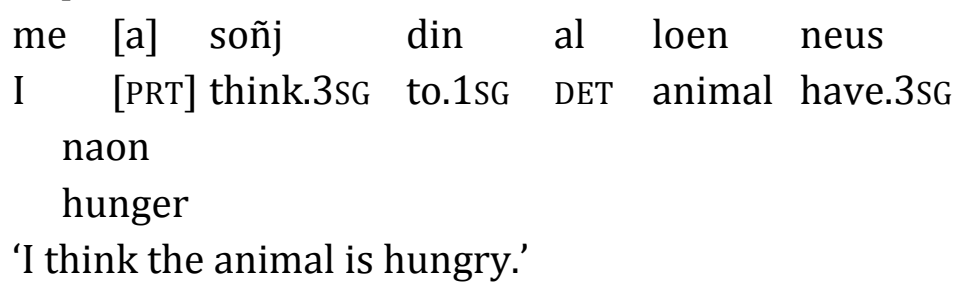


b. Non-impersonal

$\begin{array}{clllll}\text { setu ur } & \text { paotr } & \text { o } & \text { vale; } & \text { soñj } & \text { eo } \\ \text { here DET } & \text { boy } & \text { PRT } & \text { walk.PROG; think.3SG } & \text { be.3SG } \\ \text { barzh } & \text { Oxford } & & & \\ \text { in } & \text { Oxford } & & \end{array}$

'Here a boy is walking; (I) think he's in Oxford.'

There is another possible syntactic factor in CG's use of the impersonal, although the data are difficult to interpret. In (14a), he uses the verb without any agreement or personal pronoun (possibly an ellision, since an initial finite verb is not strictly grammatical in Breton), but with the impersonal din 'to me'. The complement clause is then non-finite, with the single verbal noun dañsal. This construction is typical of all four impersonal utterances in his data. In (14b), he again uses the radical form of the verb, presumably standing in for the verbal noun, with a finite auxiliary but no impersonal, and a finite complement clause. Again, this is typical of his non-impersonal utterances.

(14) Speaker CG

a. Impersonal soñj din dañsal
think.3SG to.1sG dance.VN
'I think [they're/there's] dancing.'

b. Non-impersonal

$\begin{array}{llllll}\text { soñj } & \text { a } & \text { ran } & \text { e } & \text { sav an } & \text { dorn } \\ \text { think.3SG } & \text { PRT } & \text { do.1SG } & \text { PRT } & \text { raise DET } & \text { hand } \\ \text { 'I think she's raising her hand.' }\end{array}$

It is common for the children to confuse verb stems with verbal nouns, or to leave out pronouns in this way, but this makes it difficult to determine exactly what is happening here: is there some sort of syntactic conditioning, whereby the finiteness of the complement clause affects whether the main verb is impersonal or not, or is this just variability from a speaker 
who has yet to reach adult-like proficiency? Further investigation would be needed to find out.

Finally, the data for Speaker $\mathrm{H}$, a young adult, are particularly clear-cut: his data include nineteen instances of soñjal across the two fieldwork visits; those from the first visit are impersonal, and those from the second visit are not. This highlights the potential for intraspeaker variation in two separate speech situations. A possible explanation (beyond the fact that a person may change the way they speak over a period of more than a year) is that although the elicitation task and the fieldwork context were exactly the same on both visits, there might be a perceived difference in formality. On the first occasion, the experience is completely new, and the speaker has just met the fieldworker. On the second occasion, the circumstances and task are more familiar, and the speaker already knows the fieldworker. This might therefore lead to a more informal style of speech. Of course, this is speculation, and more data are needed to establish whether this is the case, and indeed whether the impersonal form constitutes a more formal register.

\section{Mutation}

\subsection{Background}

Mutation is the process by which the initial consonant of a word is replaced by another consonant under certain morphosyntactic conditions. In Breton it affects nouns, adjectives and verbs, and there are four main types: lenition, spirantisation, provection and the mixed 
mutation. ${ }^{6}$ The discussion here focuses on the mutation of nouns following the indefinite article, which concerns primarily lenition, and, to a lesser extent, spirantisation.

Lenition is the most common form of mutation in Breton: it affects the greatest number of consonants (Table 13), and is found in the widest range of contexts.

Table 13. Lenition in Breton

\begin{tabular}{l|l|l|l|l|l|l|l|l} 
Unmutated & $\mathrm{p}$ & $\mathrm{t}$ & $\mathrm{k}$ & $\mathrm{b}$ & $\mathrm{d}$ & $\mathrm{g}$ & $\mathrm{gw}$ & $\mathrm{m}$ \\
\hline Mutated & $\mathrm{b}$ & $\mathrm{d}$ & $\mathrm{g}$ & $\mathrm{v}$ & $\mathrm{z}$ & $\mathrm{c}$ 'h $[\mathrm{h}]$ & $\mathrm{w}$ & $\mathrm{v}$
\end{tabular}

In addition to its use following the articles, lenition is found on nouns following $e$ 'his' and $d a$ 'your.SG', following the numeral two, and after certain prepositions and conjunctions. Adjectives are lenited when they modify mutated nouns and following re 'too' and gwall 'very'. Certain preverbal particles (such as negative ne and reflexive en em) and conjunctions trigger lenition on verbs. Many of these contexts are subject to exceptions: for example, the noun plac'h 'girl' never mutates following the articles, even though it would be expected to.

Spirantisation is more restricted in use than lenition, involving fewer consonants and affecting only nouns It is found following $\mathrm{ma} / \mathrm{va}$ 'my', he 'her' and $o$ 'their', and the numerals three, four and nine.

Table 14. Spirantisation in Breton

\begin{tabular}{l|l|l|l} 
Unmutated & $\mathrm{p}$ & $\mathrm{t}$ & $\mathrm{k}$ \\
\hline Mutated & $\mathrm{f}$ & $\mathrm{z}$ & $\begin{array}{l}\mathrm{c}^{\prime} \mathrm{h} \\
{[\mathrm{x}] /[\mathrm{h}]}\end{array}$
\end{tabular}

Mutation following the articles interacts with gender and number. Feminine singular nouns and human masculine plural nouns undergo lenition, and this applies to all leniting consonants except $d>z$. In addition to these patterns of lenition, masculine singular nouns

\footnotetext{
${ }^{6}$ For a full account of mutation in Breton, see e.g. Press (1986; 2009), or Ternes (1992).
} 
and all other plural nouns beginning with $k$ - undergo spirantisation. A summary of mutation following the articles is given in Table 15.

Table 15. Mutation following the articles - summary

\begin{tabular}{|c|c|c|}
\hline Noun type & Mutation & Examples \\
\hline \multirow[t]{4}{*}{ Masculine singular } & None & $t i$ 'house' > an $t i$ \\
\hline & & paotr 'boy' > ar paotr \\
\hline & Spirantisation: [k] only & kaner 'singer' > ar c'haner \\
\hline & & kazh 'cat' > ar c'hazh \\
\hline \multirow[t]{4}{*}{ Masculine plural } & None & tier 'houses' > an tier \\
\hline & Lenition: humans only & paotred 'boys' > ar baotred \\
\hline & & kanerien 'singers' > ar ganerien \\
\hline & Spirantisation: [k] only & kizhier 'cats' > ar c'hizhier \\
\hline \multirow[t]{3}{*}{ Feminine singular } & Lenition & merc'h 'girl' > ar verc'h \\
\hline & & kador 'chair' > ar gador \\
\hline & None: [d] only & dremm 'face' > an dremm \\
\hline \multirow[t]{2}{*}{ Feminine plural } & None & merc'hed 'girls' > ar merc'hed \\
\hline & Spirantisation: [k] only & kadorioù 'chairs' > ar c'hadorioù \\
\hline
\end{tabular}

Breton mutation is therefore complex and interacts with an opaque gender system. Mutation is the one of the main signals of grammatical gender in Breton; there is little about the phonology or morphology of the noun that indicates gender, although certain suffixes, such as singulative -enn, make the noun feminine. Although the numerals two, three and four agree with the gender of the noun, gender is most frequently signalled by mutation patterns. This makes the system opaque in two ways: first, not all nouns mutate, either because they do not begin with a mutable consonant (e.g. $s^{-}$) or because they are exceptions to the mutation rules (e.g. plac'h 'girl'). Secondly, there is no one-to-one relationship between gender and the realisation of the mutation; for example, lenition marks both feminine and masculine nouns, and both singular and plural.

This type of opaque system is also found in Welsh, and Hammond (2016) writes that it is difficult to determine the gender of a noun from language-internal information. Studies 
have shown Welsh gender and mutation is difficult for younger speakers to acquire (Gathercole et al., 2001; Thomas and Gathercole, 2007) and the process of acquisition may extend well into the teenage years (Thomas and Gathercole, 2007; Thomas and Mayr, 2010). Children seem to use mutation more with familiar than unfamiliar lexical items (Gathercole et al., 2001) and to be more proficient with the soft mutation (equivalent to Breton lenition) than the aspirate or nasal mutations (Hatton, 1988; Thomas and Gathercole, 2007): the soft mutation, like lenition, is more wide-ranging in terms of the consonants it affects and in the contexts in which it is found.

\subsection{Mutation: methodology}

Fieldwork was conducted in southwest Brittany, and three groups of speakers were interviewed. The senior adults and young adults were comparable with those detailed in Section 2, but a slightly different third group was included, namely, pupils aged 15-18 in Breton-medium education. Since mutation is difficult for children to acquire, working with older teenagers was thought preferable for this study.

Eleven senior adults took part (aged 57-83, mean age $=73.4$ ), all of whom had grown up speaking Breton at home. The nine young adults (aged 27-52, mean age = 38.3) who participated all identified as 'new speakers' of Breton, and had learnt it through education, occasionally with input from older family members. Finally, thirty students at a Bretonmedium lise (equivalent to the French lycée, for students aged 15-18) also took part. They were aged 14-18 at the time of the fieldwork (mean age $=16.1$ ), and although a few spoke Breton at home with family members, the majority only spoke Breton at school. In the discussion that follows, they are termed liseidi ('lycée students') to distinguish them from the Diwan and Div Yezh children who took part in the previous study. 
The data were elicited using pictures, and participants were asked to name objects in Breton, giving the word preceded by the indefinite article. Sixty images were presented, covering all leniting consonants across both genders. This naturally resulted in some variation in vocabulary, not only because speakers might interpret an image differently (e.g. face vs. head), but also because of widespread regional variation in Breton. Despite this, the method was the most suitable for the senior adults, allowing speakers to use words they were familiar with, rather than mutating an unfamiliar word. The task was explained in French, and speakers were not prompted if they did not know or could not remember the Breton word. In addition to the sixty 'mutable' images, a further fifty 'control' images were included, all of which represented words beginning with a non-mutating consonant (e.g. ur sae 'a dress').

In the analysis of the data that follows, each word that a speaker produced was assessed as to whether it had the 'expected' mutation. This refers to the model of Breton mutation presented in the previous section (see Table 15), and therefore includes lenition of a feminine singular noun, spirantisation of a masculine singular noun beginning $k^{-}$, and also the absence of mutation on a masculine noun beginning with another consonant, or any word beginning $d$ -

This model of mutation is based upon a number of descriptive grammars of Breton (e.g. Kervella, 1947; Press, 1986; Press, 2009; Stephens, 1993; Ternes, 1992), and represents both standardised Breton and many of the traditional regional varieties. The mutation system is no exception to the widespread regional variation that exists in Breton. There are two possible hypotheses for the senior adults: they may be very similar to the accounts in descriptive grammars, or they may deviate from this usage as a result of regional variation.

The young adults and liseidi may be closer to this model than the senior adults, since they have been exposed to the standardised norm rather than a local variety. Alternatively, 
they may use the expected mutation less than the senior adults, because they have not fully acquired the mutation system. The difficulty of acquiring this opaque system may lead to language change as in Dorian (1976), who finds that in East Sutherland Gaelic, some cues to gender, such as the mutation of adjectives following feminine nouns, are being lost.

\subsection{Mutation: findings}

Looking first at the data as a whole, it is clear that all groups of speakers have a good grasp of the mutation system (Table 16). The two adult groups use mutation almost identically, in over 90 per cent of instances, while the liseidi lag slightly behind this.

Table 16. Use of mutation - overall

\begin{tabular}{llrll}
\hline Group & \multicolumn{2}{l}{ Expected mutation } & \multicolumn{2}{l}{ Unexpected mutation } \\
\hline Senior adults & 364 & $93.1 \%$ & 27 & $6.9 \%$ \\
Young adults & 427 & $92.0 \%$ & 37 & $8.0 \%$ \\
Liseidi & 770 & $84.3 \%$ & 143 & $15.7 \%$ \\
\hline
\end{tabular}

This implies that in this part of Brittany, older speakers do not differ substantially in their use of mutation following the article from the more general descriptions referred to above.

It seems sensible to begin by exploring the category of 'unexpected' mutations, and establishing what forms these take. This category comprises anything that deviates from the model of mutation given in section 3.1, and might therefore mean an absence of an expected mutation, or the substitution of one mutation for another (e.g. spirantisation for lenition, or vice versa). 
Table 17. 'Unexpected' mutations by type

\begin{tabular}{lllll}
\hline \hline Masculine nouns & & & & \\
\hline \hline Group & $\begin{array}{l}\text { No mutation } \\
\text { of k- }\end{array}$ & $\begin{array}{l}\text { Lenition } \\
\text { of k- }\end{array}$ & $\begin{array}{l}\text { Lenition } \\
\text { of other } \\
\text { consonants }\end{array}$ & Other \\
\hline Senior adults & 0 & 0 & 1 & 0 \\
Young adults & 1 & 0 & 9 & 1 \\
Liseidi & 5 & 1 & 23 & 1 \\
\hline Feminine nouns & & & & Other \\
\hline Group & No mutation & Spirantisation & 1 \\
\hline Senior adults & 22 & 3 & & 0 \\
Young adults & 24 & 2 & 2 \\
Liseidi & 101 & 10 & & \\
\hline \hline
\end{tabular}

Table 17 shows that most deviations involve the absence of mutation on feminine nouns, and the lenition of masculine nouns beginning with consonants other than $/ \mathrm{k} /$. (The classification 'other' refers to cases which did not fit any of these mutations, such as pluñvenn 'feather.F' > ur vluñvenn.) The question arises as to whether anything is conditioning the appearance of unexpected mutations, such as the gender of the noun, the initial consonant of the word, or more specific lexical effects. Equally, this overall picture might mask interspeaker variation.

Examining this latter question first, Figure 1 shows that the two adult groups are highly consistent in usage; particularly the younger adults, whose data are highly clustered with few outliers. This contrasts with previous findings for word order, for example, where younger adults seem to exhibit a higher degree of interspeaker variation (Kennard, 2014). Here, all adult speakers use the expected mutation at least 85 per cent of the time, although the speakers who are closest to 'expected usage' are senior adults. There is more variation among the liseidi, but this is perhaps unsurprising: this is a larger group, and the mean usage was lower overall. However, all liseidi use the expected mutation in at least 66 per cent of 
instances: a greater proportion than was found for studies involving younger children (e.g. Kennard and Lahiri, 2017).

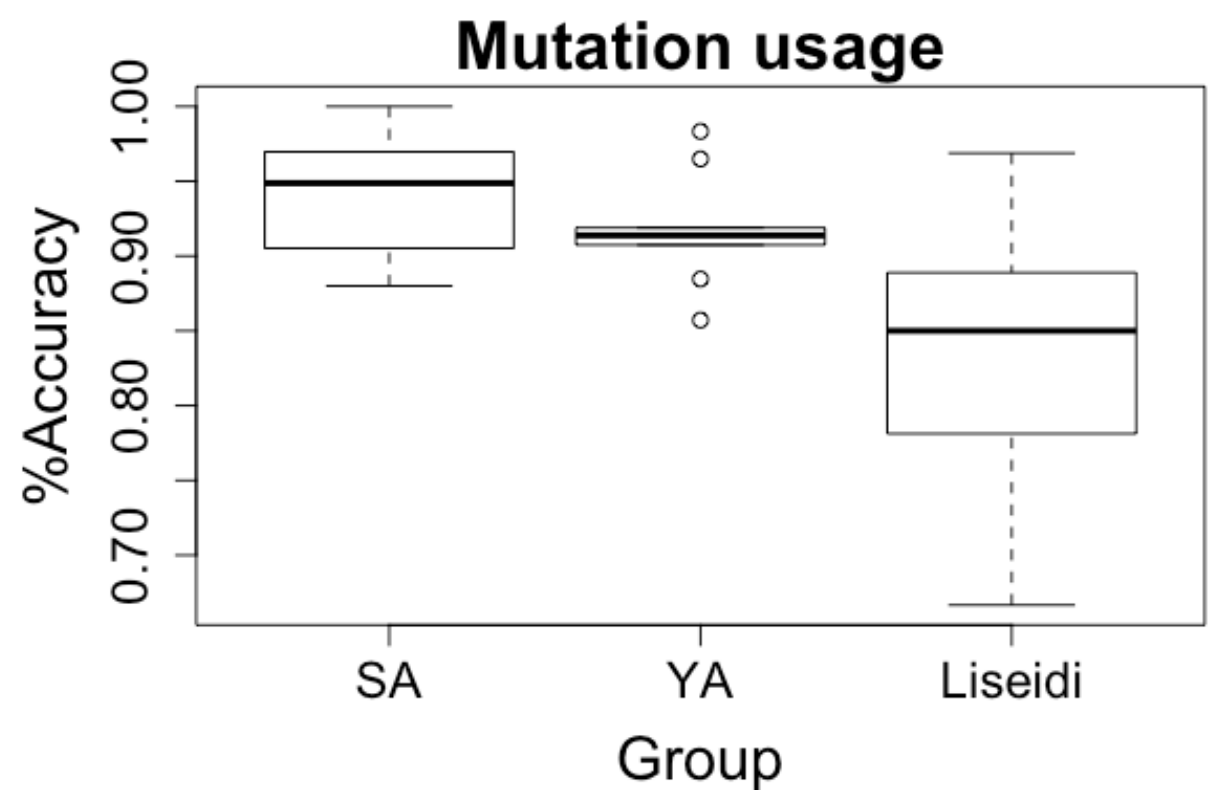

Figure 1. Use of the 'expected' mutation across three speaker groups

Turning now to other potential conditioning factors, a Generalised Linear Model was applied to the data to investigate these factors further, with the dependent factor Mutation Type (expected/unexpected) and the independent variables Group (senior adults, young adults, liseidi) and Gender of the noun (masculine/feminine). Initial Consonant was not included as a variable, because for some consonants $(/ \mathrm{g} /$, and feminine nouns with $/ \mathrm{t} /)$ there are very few observations.

Looking at the results as a whole, it is clear that there are significant differences between the groups $\left(\mathrm{X}^{2}=138.13 \mathrm{df}=5, p<0.0001\right)$. There were significant main effects of Group $(p<0.0001)$ and Gender $(p<0.0001)$ and the interaction Group $\times$ Gender was significant $(p=0.012)$.

To examine the data in a little more detail, pairwise comparisons were performed for the interaction Group $\times$ Gender. These showed that for masculine nouns, the senior adults 
were significantly different from both the young adults $(p=0.029)$ and the liseidi $(p=$ 0.0001), while there was no significant difference between the young adults and the liseidi. For feminine nouns the situation is slightly different: the liseidi are significantly different from both the senior adults $(p=0.0002)$ and the young adults $(p<0.0001)$. The data are divided according to Gender and Group in Table 18.

Table 18. Use of mutation by gender and group

\begin{tabular}{llllll}
\hline Gender & Group & Expected & \multicolumn{2}{l}{ Unexpected } \\
\hline \multirow{3}{*}{ Masculine } & SA & 194 & $99.5 \%$ & 1 & $0.5 \%$ \\
& YA & 216 & $95.2 \%$ & 11 & $4.8 \%$ \\
& Liseidi & 452 & $93.8 \%$ & 30 & $6.2 \%$ \\
\hline \multirow{5}{*}{ Feminine } & Total & 841 & $95.3 \%$ & 42 & $4.7 \%$ \\
& SA & 170 & $86.7 \%$ & 26 & $13.3 \%$ \\
& YA & 211 & $89.0 \%$ & 26 & $11.0 \%$ \\
& Liseidi & 318 & $73.8 \%$ & 113 & $26.2 \%$ \\
\hline
\end{tabular}

Speakers use the expected mutation less with feminine than masculine nouns, which makes sense: most masculine nouns do not undergo mutation following the indefinite article, while most feminine nouns do. Speakers may be more likely to use the citation form of the noun than insert a mutation where it would not normally be expected.

However, by this argument, we might expect that speakers would make more errors with masculine nouns beginning $k$-, since these nouns do require a mutation (spirantisation), unlike other masculine nouns. As Table 19 shows, this is not the case, and speakers are just as accurate with $k$-initial nouns. This may be because there are more masculine than feminine nouns in Breton (Irslinger, 2014), and so the masculine is the default gender. That is not to say that masculine nouns are more frequently used than feminine nouns: frequency in the input is likely to play an important role in what speakers regard as the default gender, but determining what speakers receive as Breton input is difficult, and likely to vary substantially 
across speakers. In his study of Welsh gender, however, Hammond (2016) remarks that an approach to determining the gender of Welsh nouns that uses 'guess masculine' is as accurate as using language-internal cues. It seems likely that the larger number of masculine nouns may also play a role in Breton.

Table 19. Use of mutation by gender and consonant

\begin{tabular}{llll}
\hline Consonant & Gender & Expected & Unexpected \\
\hline $\mathrm{p}$ & $\mathrm{M}$ & 157 & 6 \\
& $\mathrm{~F}$ & 158 & 20 \\
\hline $\mathrm{t}$ & $\mathrm{M}$ & 196 & 3 \\
& $\mathrm{~F}$ & 13 & 2 \\
\hline $\mathrm{k}$ & $\mathrm{M}$ & 208 & 8 \\
& $\mathrm{~F}$ & 150 & 18 \\
\hline $\mathrm{b}$ & $\mathrm{M}$ & 98 & 19 \\
& $\mathrm{~F}$ & 134 & 31 \\
\hline $\mathrm{d}$ & $\mathrm{M}$ & 46 & 0 \\
& $\mathrm{~F}$ & 43 & 0 \\
\hline $\mathrm{g}$ & $\mathrm{M}$ & 11 & 0 \\
& $\mathrm{~F}$ & 7 & 27 \\
\hline $\mathrm{gw}$ & $\mathrm{M}$ & 55 & 4 \\
& $\mathrm{~F}$ & 81 & 17 \\
\hline $\mathrm{m}$ & $\mathrm{M}$ & 70 & 2 \\
& $\mathrm{~F}$ & 94 & 55 \\
\hline
\end{tabular}

Table 19 also seems to indicate that certain consonants are more likely to be mutated as expected than others, a factor which was considered above. However, on closer inspection it becomes clear that this is actually a lexical effect: certain nouns are more likely to receive an unexpected mutation than others. The feminine maneg 'glove' is left unmutated in 18 of 25 instances, while the masculine broust 'brush' is lenited in 20 of 34 cases. Given its similarity to the French feminine brosse 'brush', it is possible that there is some sort of interference here, leading speakers to treat this as feminine. Other nouns that have a similar pattern include $g o z$ 'mole' (F), goulaouenn 'candle' (F), gwastell 'cake' (F) and milin 'mill' (F), as shown in Figure 2. 


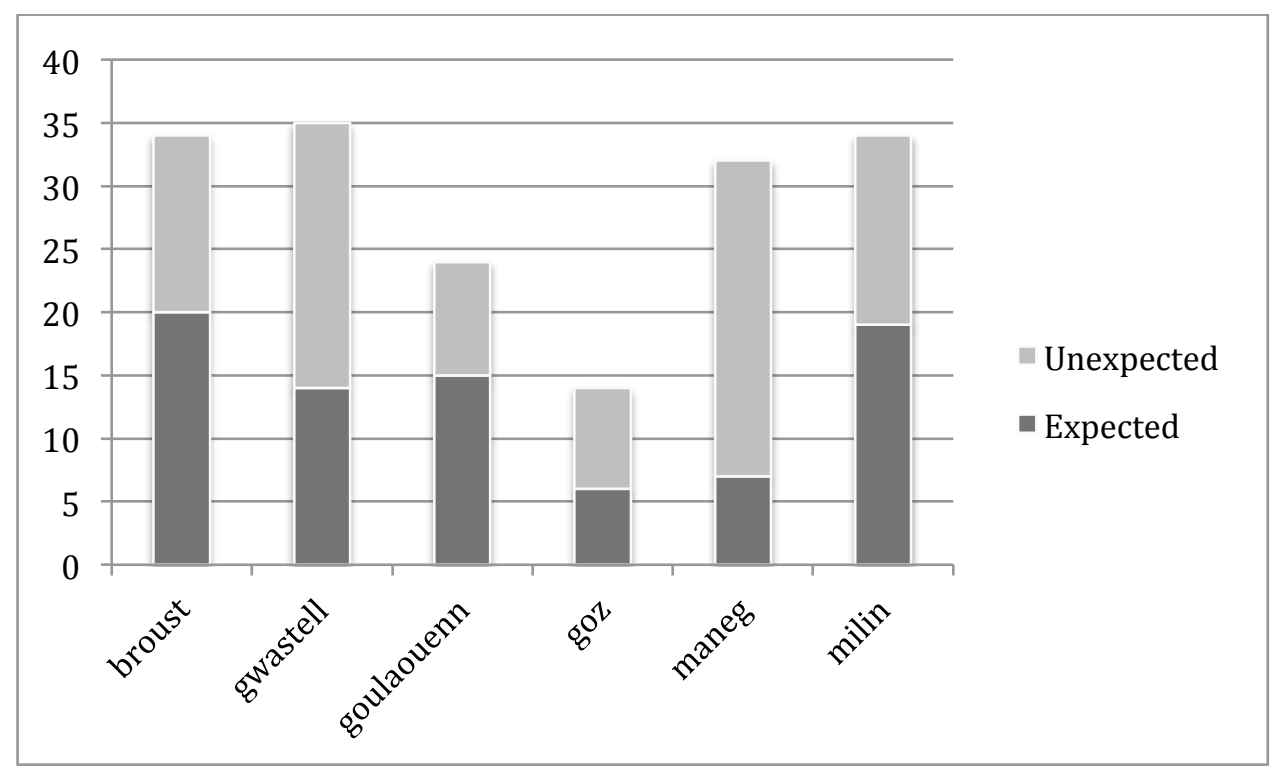

Figure 2. Nouns receiving a high proportion of unexpected mutation

What impact might semantic domain have on speakers' use of mutation? Although Breton gender is largely arbitrary, it is usual for it to align with biological sex in humans and (some) animals, as in many gender systems (Corbett, 1991): den 'man' is masculine, while maouez 'woman' is feminine. In this study there are five human nouns: paotr 'boy', merc'h 'girl', den 'man', maouez 'woman', and mamm-gozh 'grandmother'. We would expect that these would show relatively few cases of unexpected mutation, as is indeed the case: only maouez and mamm-gozh have any unexpected forms, with the mutation being omitted in two (of 11) and five (of 29) instances respectively. These come from the liseidi, suggesting that a small number of these speakers may be having difficulties with the mutation patterns of Breton, but that this does not apply to the majority of Neo-Breton speakers.

The interaction between Group and Gender in the GLM reported above indicates that while the senior adults differ significantly from the two younger groups with respect to masculine nouns, the picture for feminine nouns is slightly different, with both adult groups being significantly different from the liseidi, but not each other. Why this asymmetry? Use of 
the expected mutation is high overall for masculine nouns: all three groups use the expected mutation over 90 per cent of the time. For the younger adults, six of the eleven instances of unexpected mutation involve the noun broust 'brush', which has already been identified as problematic. However, mutation of feminine nouns seems to be more challenging for all speakers, and here the difference between the liseidi and the two adult groups is particularly apparent. The younger adults use the expected mutation slightly less often than the senior adults, but this is not a significant difference.

Therefore, the mutation data are similar to the impersonal data: the difference between the two adult groups is very small, and observable only with masculine nouns, where expected usage is generally high. The liseidi lag behind adult usage, suggesting that they are continuing to reach adult proficiency in their late teens. However, these new speakers do not appear to be confused about or to omit mutation in their Breton, as some have claimed. It seems likely that speakers are uncertain not about the mutation system itself (they are able to apply the mutation rules most of the time), but about the gender of certain nouns - not surprising in an opaque gender system like that of Breton. Additionally, all speakers of Breton are also fluent speakers of French, which has its own gender system. There is thus the possibility for interference between Breton and French, where additionally, the gender system may be largely arbitrary (e.g. there is nothing intrinsically masculine or feminine about a house), but it is much less opaque (i.e. it has a largely regular system of agreement with determiners and adjectives). Speakers of Breton therefore have an additional, competing gender system which is absent for speakers of Welsh. 


\section{Discussion and conclusions}

This paper has examined morphosyntactic and morphophonological data with a view to investigating how younger speakers of Breton may differ from older traditional speakers, and whether there is influence from French. If the Breton of these new speakers differed sharply from that of older speakers, it might be an indication that widespread change is occurring in the language as a result of its decline and revitalisation, and the consequent gap in language transmission. Additionally, all speakers are bilingual, and younger speakers come largely from French-speaking homes: it would not be surprising to find influence from French in their Breton.

Looking at impersonal verbs, it seems that there are fewer differences between the generations than we might expect from claims regarding Neo-Breton morphosyntax (Hewitt, 2017; McDonald, 1989). Children in Breton-medium education rarely use these verbs impersonally, but younger adults do not differ significantly from older adults in their use of these verbs. Rather, it seems that there is much interspeaker variation, and speakers may prefer one construction over another for any particular verb; this is true of older speakers as much as younger speakers.

In contrast, the speaker groups differ in the use of constructions with plijout vs. plijadur. Younger speakers are more likely to use plijout (da) to mean 'to like, to enjoy', but in the corpus under consideration here, older speakers prefer the noun plijadur. This might be a regional feature specific to south-west Brittany, which is lost in standardised Neo-Breton. Alternatively, perhaps Neo-Breton speakers are using French plaire as an analogy for plijout that is not generally found among the older generation of speakers anywhere in Brittany; further research is needed to shed more light on this. 
The data on intraspeaker variation are somewhat limited, but seem to indicate that both syntactic factors (such as clause structure) and extra-linguistic factors (such as context or familiarity) may play a role in speakers' use of the impersonal form. These may not be the same for all groups of speakers, but the data are too sparse to be certain.

The findings regarding mutation indicate that all speakers use mutation after the indefinite article reasonably proficiently. Both groups of adults use the expected mutation more frequently than the teenagers. Speakers are more accurate with masculine than feminine nouns, and the majority of unexpected usage is concentrated in a small group of nouns, suggesting that it is the gender of the noun that varies, rather than the system of mutation. For some nouns, such as broust 'brush' and milin 'mill', their similarity to their French equivalents may be influencing speakers to assign the same gender as in French. Of course, this is only one mutation context, and a more comprehensive picture of mutation usage could be obtained by looking at additional contexts, as well other types of mutation. Dorian (1977) finds that the loss of lenition in East Sutherland Gaelic follows a strict hierarchy, beginning with less frequent and less salient contexts such as lenition following adverbs and numerals, and only later spreading to lenition of a feminine noun following the article.

As an aside, it is worth noting that the two sets of data come from slightly different elicitation paradigms. The impersonal data were elicited under less constrained conditions and are likely to have resulted in more naturalistic speech. The mutation data were gathered through single-word elicitation, which could result in more careful speech, with speakers more conscious of what is regarded as 'correct'. The importance of this (the attention that speakers pay to their speech, and the impact this has) has long been known and discussed in the sociolinguistic literature (e.g. Labov, 1972; Labov, 2001; Trudgill, 1974). In future 
research, it would be valuable to explore stylistic variation of this type across different linguistic phenomena in the speech of both traditional and neo speakers.

In both impersonal verbs and mutation, it is the youngest group, still in Bretonmedium education, which differs, suggesting that while there is a prolonged period of acquisition, it is possible for these speakers to attain full proficiency in Breton. Another factor may be relevant here: the young adults who took part in this study all use Breton in their dayto-day lives, at work and in most cases at home. These speakers have therefore continued to use Breton beyond immersion schooling, and have chosen careers where their ability to speak Breton is central. Potentially these speakers represent the most proficient speakers to come out of Breton-medium schooling, and pupils whose Breton is further from adult norms may not go on to use the language in adulthood. Baudu (2015) explores the extent to which former Diwan pupils continue to use Breton once they have left school, and whether they use Breton with their own children, and finds that speakers who continue to interact with a close-knit peer group from the school are more likely to continue to use the language in adulthood. Encouraging pupils to use Breton outside the classroom setting is one of the biggest challenges facing Breton-medium schools (Chauffin, 2015; Ó hIfearnáin, 2011), and the same issue is echoed in other Celtic languages (Dunmore, 2018; Smith-Christmas, 2017).

In sum, the differences between the older and younger groups of Breton speakers are much more subtle than we might suppose based on claims surrounding Neo-Breton (e.g. Hewitt, 1977; Hewitt, 2017; Jones, 1995; Jones, 1998b; McDonald, 1989). The process of acquisition seems to extend well into the teenage years, possibly because the input is much reduced in comparison to acquiring a language at home. There is also less influence from French than might be expected from earlier discussion of Neo-Breton (Delanoy, 1990; 
German, 2007; Hornsby, 2005; McDonald, 1989); rather than affecting the system directly, it seems that certain Breton patterns are extended at the expense of others.

\section{References}

Adkins, M. (2013). Will the real Breton please stand up? Language revitalization and the problem of authentic language. International Journal of the Sociology of Language, 223, $55-70$.

Baudu, T. (2015). "From pupil to parent": Understanding former Diwan pupils' attitudes, challenges and opportunities in revitalizing the Breton language transmission within the family. Bangor University

Bentahila, A. \& Davies, E. E. (1993). Language Revival: Restoration or transformation? Journal of Multilingual and Multicultural Development, 14, 355-374.

Bocquenet, L. (1985). Pourquoi DIWAN? Multilingua, 4, 211-215.

Broudic, F. (1995). La Pratique du Breton de l'Ancien Régime à nos jours. Rennes: Presses Universitaires de Rennes.

Broudic, F. (2009). Parler breton au XXIe siècle: Le nouveau sondage de TMO-Régions. Brest: Emgleo Breiz.

Campbell, L. \& Muntzel, M. C. (1989). The structural consequences of language death. In Dorian, N. C. (Ed.), Investigating obsolescence: studies in language death. Cambridge: Cambridge University Press,

Chauffin, F. (2015). Diwan, pédagogie et créativité: approche critique des relations entre pédagogie, créativité et revitalisation de la langue bretonne dans les écoles associatives immersives Diwan. Université Rennes 2

Corbett, G. (1991). Gender. Cambridge: Cambridge University Press. 
Davies-Deacon, M. (2017). The online presence of standard and non-standard Breton. French Studies University of Durham.

Delanoy, A. (1990). Breton and the Word Order Concept. Word, 41, 219-221.

Dołowy-Rybińska, N. (2016). Language attitudes and community engagement: Diwan - the Breton immersion high school through the eyes of its pupils. Journal of Language, Identity \& Education, 15, 280-292.

Dorian, N. C. (1973). Grammatical Change in a Dying Dialect. Language, 49, 413-438.

Dorian, N. C. (1976). Gender in a terminal Gaelic dialect. Scottish Gaelic Studies, 12, 279-282.

Dorian, N. C. (1977). A Hierarchy of Morphophonemic Decay in Scottish Gaelic Language Death: The Differential Failure of Lenition. Word, 28, 96-109.

Dorian, N. C. (1978). The fate of morphological complexity in language death: Evidence from East Sutherland Gaelic. Language, 54, 590-609.

Dressler, W. U. (1972). Allegoregeln rechfertigen Lentoregeln: sekundäre Phoneme des Bretonischen. Innsbruck: Innsbruck Institut für Sprachwissenschaft.

Dunmore, S. (2018). Bilingual life after school: Opportunity, choice and ideology among former Gaelic-medium students. Transactions of the Gaelic Society of Inverness.

Gathercole, V. C. M., Thomas, E. M. N. \& Laporte, N. I. (2001). The acquisition of grammatical gender in Welsh. Journal of Celtic Language Learning, 6, 53-87.

German, G. (2007). Language Shift, Diglossia and Dialectal Variation in Western Brittany: the Case of Southern Cornouaille. In Tristram, H. L. C. (Ed.), The Celtic Languages in Contact: Papers from the Workshop within the Framework of the XIII International Congress of Celtic Studies, Bonn, 26-27 July 2007. Potsdam: Potsdam University Press, pp. $146-192$. 
Goalabré, F. (2011). Parental choice of minority language education in language shift situations in Brittany and Scotland. Open University

Gwegen, J. (1975). La Langue bretonne face à ses oppresseurs. Quimper: Nature et Bretagne.

Hammond, M. (2016). Predicting the gender of Welsh nouns. Corpus Linguistics and Linguistic Theory, 12, 221-261.

Hatton, L. (1988). The development of the nasal mutation in the speech of schoolchildren. In Ball, M. J. (Ed.), The Use of Welsh: A Contribution of Sociolinguistics. Clevedon: Multilingual Matters, pp. 239-257.

Hemon, R. (1941). Grammaire bretonne. Brest: Al Liamm.

Hemon, R. (1975). A Historical Morphology and Syntax of Breton. Dublin: Dublin Institute of Advanced Studies.

Hewitt, S. (1977). The Degree of Acceptability of Modern Literary Breton to Native Breton Speakers. University of Cambridge

Hewitt, S. (2002). The Impersonal in Breton. Journal of Celtic Linguistics, 7, 1-38.

Hewitt, S. (2017). Neo-speakers of endangered languages: theorizing failure to learn the language properly as creative post-vernacularity. Journal of Celtic Linguistics, 18, 127154.

Hoare, R. (2000). Linguistic Competence and Regional Identity in Brittany: Attitudes and Perceptions of Identity Journal of Multilingual and Multicultural Development, 21, 324346.

Hornsby, M. (2005). Néo breton and questions of authenticity. Estudios de Sociolingüística, 6, 191-218.

Hornsby, M. (2015). The "new" and "traditional" speaker dichotomy: bridging the gap. International Journal of the Sociology of Language, 2015, 107-125. 
Hornsby, M. (2017). Finding an ideological niche for new speakers in a minoritised language community. Language, Culture and Curriculum, 30, 91-104.

Irslinger, B. (2014). The gender of abstract noun suffixes in the Brittonic languages. In Neri, S. \& Schuhmann, R. (Eds.), Studies on the collective and feminine in Indo-European from a diachronic and typological perspective. Leiden; Boston: Brill, pp. 57-113.

Jaffe, A. (2015). Defining the new speaker: theoretical perspectives and learner trajectories. International Journal of the Sociology of Language, 2015, 21-44.

Jones, M. C. (1995). At What Price Language Maintenance? Standardization in Modern Breton. French Studies: A Quarterly Review, 49, 424-438.

Jones, M. C. (1998a). Death of a Language, Birth of an Identity: Brittany and the Bretons. Language Problems and Language Planning, 22, 129-142.

Jones, M. C. (1998b). Language Obsolescence and Revitalization: Linguistic Change in Two Sociolinguistically Contrasting Welsh Communities. Oxford: Clarendon Press.

Jouitteau, M. (2005). Nominal Properties of vPs in Breton: A Hypothesis for the Typology of VSO Languages. In Carnie, A., Harley, H. \& Dooley, S. A. (Eds.), Verb First: On the Syntax of Verb-Initial Languages. Amsterdam/Philadelphia: John Benjamins Publishing Company, pp. 265-280.

Jouitteau, M. (2010). La syntaxe comparée du breton: une enquête sur la périphérie gauche de la phrase bretonne. Saarbrücken: Éditions universitaires européennes.

Jouitteau, M. (2011). Post-syntactic Excorporation in Realizational Morphology: Breton Analytic Tenses. In Carnie, A. (Ed.), Formal Approaches to Celtic Linguistics. Newcastle upon Tyne: Cambridge Scholars Publishing, pp. 115-142.

Jouitteau, M. (2018). Children prefer natives: a study on the transmission of a heritage langugage; Standard Breton, neo-Breton and traditional dialects. 
Kennard, H. J. (2013). Breton morphosyntax in two generations of speakers: evidence from word order and mutation. University of Oxford

Kennard, H. J. (2014). The persistence of verb second in negative utterances in Breton. Journal of Historical Linguistics, 4, 1-39.

Kennard, H. J. (2018a). Non-negative word order in Breton: maintaining verb-second. Transactions of the Philological Society, 116, 153-178.

Kennard, H. J. (2018b). Verbal mutation among young speakers of Breton: Acquisition and maintenance. In Hornsby, M., Moriarty, M., Smith-Christmas, C. \& Ó Murchadha, N. (Eds.), New Speakers of Minority Languages: Linguistic Ideologies and Practices. Basingstoke: Palgrave Macmillan, pp. 231-252.

Kennard, H. J. \& Lahiri, A. (2017). Mutation in Breton verbs: Pertinacity across generations. Journal of Linguistics, 53, 113-145.

Kervella, F. (1947). Yezhadur bras ar brezhoneg. La Baule: Skridou Breizh.

Kuter, L. (1999). The Diwan Phenomenon: A Catalyst for Change in the Schools of Brittany. In Blanchet, P., Breton, R. \& Schiffman, H. (Eds.), Les langues régionales de France: un état des lieux à la veille du XXIe siècle. Actes d'un colloque organisé à «The University of Pennsylvania, Philadelphia, USA». Louvain-la-Neuve: Peeters, pp. 177-183.

Labov, W. (1972). Sociolinguistic Patterns. Philadelphia: University of Pennsylvania Press.

Labov, W. (2001). Principles of Linguistic Change, Vol II: Social Factors. Oxford: Blackwell.

Le Coadic, R. (2013). À propos des relations entre langue et identité en Bretagne. International Journal of the Sociology of Language, 223, 23-41.

Le Nevez, A. (2006). Language diversity and linguistic identity in Brittany: a critical analysis of the changing practice of Breton. University of Technology, Sydney 
Le Pipec, E. (2013). Les trois ruptures sociolinguistiques du breton. International Journal of the Sociology of Language, 2013, 103-116.

Le Ruyet, J.-C. (2011). Effet Buben, liaison et modèles orthographiques bretons. La Bretagne Linguistique, 16, 97-109.

Madeg, M. (2010). Traité de prononciation du Breton du Nord Ouest. Brest: Emgleo Breizh.

McDonald, J. H. (2014). Handbook of Biological Statistics (3rd ed.). Baltimore, Maryland: Sparky House Publishing.

McDonald, M. (1989). 'We are not French!' Language, culture and identity in Brittany. London; New York: Routledge.

McLeod, W. \& O'Rourke, B. (2015). "New speakers" of Gaelic: Perceptions of linguistic authenticity and appropriateness. Applied Linguistics Review, 6, 151-172.

Moore, J. \& Perlmutter, D. (2000). What Does It Take to be a Dative Subject? Natural Langauge \& Linguistic Theory, 18, 373-416.

Nance, C. (2015). 'New' Scottish Gaelic speakers in Glasgow: A phonetic study of language revitalisation. Language in Society, 44, 553-579.

Nance, C., McLeod, W., O'Rourke, B. \& Dunmore, S. (2016). Identity, accent aim, and motivation in second language users: New Scottish Gaelic speakers' use of phonetic variation. Journal of Sociolinguistics, 20, 164-191.

NeSmith, R. K. (2003). Tūtū's Hawaiian and the Emergence of a Neo Hawaiian Language. 'Ōiwi - A Native Hawaiian Journal, 3.

Ó hIfearnáin, T. (2011). Breton language maintenance and regeneration in regional education policy. In Norrby, C. \& Hajek, J. (Eds.), Uniformity and diversity in language policy: Global perspectives. Bristol: Multilingual Matters, pp. 93-108. 
O'Rourke, B. (2018). Just use it! Linguistic conversion and identities of resistance amongst Galician new speakers. Journal of Multilingual and Multicultural Development, 39, 407418.

O'Rourke, B., Pujolar, J. \& Ramallo, F. (2015). New speakers of minority languages: the challenging opportunity - Foreword. International Journal of the Sociology of Language, 2015, 1-20.

Palosaari, N. \& Campbell, L. (2011). Structural aspects of language endangerment. In Austin, P. K. \& Sallabank, J. (Eds.), The Cambridge Handbook of Endangered Languages. Cambridge: Cambridge University Press, pp. 100-119.

Press, J. I. (1986). A Grammar of Modern Breton. Berlin: Mouton de Gruyter.

Press, J. I. (2009). Breton. In Ball, M. J. \& Müller, N. (Eds.), The Celtic Languages. London; New York: Routledge, pp. 427-487.

Smith-Christmas, C. (2017). "Is it really for talking?": the implications of associating a minority language with the school. Language, Culture and Curriculum, 30, 32-47.

Smith-Christmas, C., Ó Murchadha, N., Hornsby, M. \& Moriarty, M. (Eds.) (2018). New speakers of minority languages: linguistic ideologies and practices. Basingstoke: Palgrave Macmillan.

Stephens, J. (1993). Breton. In Ball, M. J. \& Fife, J. (Eds.), The Celtic Languages. London: Routledge, pp. 349-409.

Ternes, E. (1992). The Breton Language. In MacAulay, D. (Ed.), The Celtic Languages. Cambridge: Cambridge University Press, pp. 371-452.

Thomas, E. M. \& Gathercole, V. C. M. (2007). Children's productive command of grammatical gender and mutation in Welsh: an alternative to rule-based learning. First Language, $27,251-278$. 
Thomas, E. M. \& Mayr, R. (2010). Children's Acquisition of Welsh in a Bilingual Setting: A Psycholinguistic Perspective. In Morris, D. (Ed.), Welsh in the Twenty-First Century. Cardiff: University of Wales Press, pp. 99-117.

Trudgill, P. (1974). The Social Differentiation of English in Norwich. Cambridge: Cambridge University Press.

Walter, H. (1999). On the Trail of France's Regional Languages. In Blanchet, P., Breton, R. \& Schiffman, H. (Eds.), Les langues régionales de France un état des lieux à la veille du XXIème siècle. Actes d'un colloque organisé à «The University of Pennsylvania, Philadelphia, USA». Louvain-la-Neuve: Peeters, pp. 15-24. 